\title{
Framing-effects approach: A theoretical and methodological critique
}

\author{
BERTRAM SCHEUFELE
}

\section{Abstract}

The article deals with research on framing effects. First, I will start with classifying different approaches on framing. Subsequently, I will provide a definition of the concepts of frame, schema and framing, expand on framing research conducted so far - both theoretically and operationally. Having this equipment at hand, I will initiate a discussion on studies of framingeffects in terms of theory, methods and empirical results. This discussion leads to the conclusion that studies on framing effects are insufficiently concerned with the more recent psychological constructs and theories. In merely focusing on the activation of schemata, most studies ignore the more elaborate types of framing-effects. Therefore, several empirical questions remain unanswered and some methodical chances seem to be wasted.

Keywords: frame, framing, schema, cognition, media effects

\section{Introduction}

The concept of framing is considered to be one of the most prominent features within the field of communication science; the same applies to the concept of 'fractured paradigm' (Entman, 1993: 51). This article does not discuss all approaches to framing, but deals with framing-effects on media recipients, that is, media users. After giving a short overview of research on framing, I will define the constructs 'frame', 'schema' and 'framing'. This article, however, will mainly focus on a discussion of studies on framing-effects in terms of theory, methods and empirical results.

\section{Framing approach}

For a synopsis of the framing approach, a model-related classification comparable to the one for agenda-setting (e.g., Rogers and Dearing, 1988) - seems to be appropriate (Scheufele, 2003). It takes into account 
disparate theories and methods. However, the question that can be raised is how to define a frame; what is framing?

Several definitions of 'frame' and 'framing' (e. g., Entman, 1993; Gitlin, 1980; Gamson and Modigliani, 1989; Pan and Kosicki, 1993; Tankard, 2001; Reese, 2001; Scheufele, 1999) share a number of assumptions. Frames are seen as patterns of interpretation through which people classify information in order to handle it efficiently. Framing emphasizes specific aspects of reality (Snow and Benford, 1988; Cappella and Jamieson, 1997; Pan and Kosicki, 1993; Reese, 2001); furthermore, specific attributions, evaluations or decisions are assigned to recipients (Iyengar, 1991; Price, Tewksbury, and Powers, 1997; Shah, Domke, and Wackman, 1996; Gamson and Modigliani, 1989).

As Figure 1 indicates, frames - respectively framing - can be identified at three (system) levels. First, at a horizontal level (Scheufele, 1999a; see also Entman, 1993; Tuchman, 1978; Scheufele and Brosius, 1999): (1) journalists or the media system, (2) recipients or society and (3) political, economical, cultural, etc., actors, groups or organizations. Also, many authors set frames on a cognitive or a textual level. Others (e. g., Kinder and Sanders, 1990; Gamson, 1992) see frames as patterns of public discourse. Thus, also at a vertical level a frame can be identified in three ways (see Figure 1$)^{1}$ : (1) as a cognitive complex of related schemata for references, such as events, causes, consequences (Scheufele, 2003: 65), (2) in public or inter-media discourse, and (3) as a textual structure of discourse products (e. g., press releases, newspaper articles).

\begin{tabular}{|l|l|l|l|}
\cline { 2 - 4 } \multicolumn{1}{c|}{} & \multicolumn{3}{l|}{ System areas (selection) } \\
\hline $\begin{array}{l}\text { Levels } \\
\text { Politicians / }\end{array}$ & $\begin{array}{l}\text { Journalists / } \\
\text { Media system }\end{array}$ & $\begin{array}{l}\text { Recipients / } \\
\text { Society }\end{array}$ \\
\hline $\begin{array}{l}\text { Level of } \\
\text { cognition }\end{array}$ & 1 & 4 & 7 \\
\hline $\begin{array}{l}\text { Level of } \\
\text { discourse }\end{array}$ & 2 & 5 & 8 \\
\hline $\begin{array}{l}\text { Level of } \\
\text { discourse } \\
\text { product }\end{array}$ & 3 & 6 & 9 \\
\hline
\end{tabular}

Note: Shading indicates, which level or area is under study by which approach.

Communicator approach - cognition studies

Communicator approach - coverage studies

Public discourse approach / social movement approach

Media effects approach

Figure 1. Perspectives of framing approach. 
This classification allows for the specification of three branches of framing research (Scheufele, 2003):

(1) The communicator approach either concentrates on journalists' cognitions or on media coverage. A sub-field within this approach, which I will call cognition studies, (e.g., Scheufele, 2003; Scheufele and Brosius, 1999; Gitlin, 1980; Tuchman, 1972, 1978) is concerned with journalistic frames (cells 4 and 5 in Figure 1), that is, journalists' cognitions as criteria of news production. Studies which claim to examine how these cognitive frames influence news production and, subsequently, how they are presented as media frames in news reporting are noted in cell 6. What I call coverage studies (e.g., Entman, 1991; Pan and Kosicki, 1993; Woo, 1996) merely trace structures of coverage, that is, media frames (cell 6). Both perspectives of the communicator approach will be discussed in some detail.

(2) The public discourse or social movement approach (e.g., Gamson, 1992; Gamson and Modigliani, 1989; Snow and Benford, 1988) has a macro focus. Here, studies examine which political actors (cell 2) can launch their frames in the media (cells 5 and 6). Media, in this context, are seen as 'carriers' for the frames of others (cells 2 and 8) and media content (cell 6) serves as an indicator for the examination of discourse.

(3) The media effects approach (e. g., Iyengar, 1991; Nelson, Oxley, and Clawson, 1997; Park and Kosicki, 1995; Price et al., 1997; Rhee, 1997; Shah et al., 1996; Valkenburg, Semetko, and De Vreese, 1999) will be examined in more detail later. For now it is sufficient to mention that studies examine how media framing (cell 6) influences schemata, attitudes, emotions and decisions of media recipients, that is, media users (cell 7). Thus, this approach goes beyond the level of mere cognition.

\section{Terminology - Frame, schema, framing}

A discussion of framing-effects studies needs a standard terminology, which can be applied to all research. A first attempt toward such a terminology will be made in this section of the article. Most researchers (e. g., Entman, 1993: 52; Gitlin, 1980: 7; Valkenburg et al., 1999: 551) define a 'frame' analogously to 'schema' (e. g., Higgins, Rholes, and Jones, 1981; Fiske and Taylor, 1991; Wicks, 1992). This would make the frame construct obsolete. In contrast, I will continue to use terms such as 'schema' or 'script' and integrate 'frame' differently. I claim that a cognitive 
schema refers to a singular object or relation between objects. One person's schemata for different objects or relations can form a consistent complex of expectations which I call a cognitive frame. It refers to a collection of objects and relations (Scheufele, 1999a, 2000, 2003). To give an example, a person's 'victim-of-terrorism-schema' refers to victims of terror attacks; the subject, for example, assumes politicians to be typical victims. His or her 'causes-for-terrorism-schema' refers to objects causally related to terrorism. Here, for example, the subject assumes international politics to be the main reason for terrorism. The subject's victimand causes-schema are part of a coherent cognitive frame of reference for terrorism as a whole - and this frame can be labeled 'political frame', as all objects and relations are seen as political ${ }^{2}$.

The draft outlined here integrates psychological and sociological considerations that were mostly neglected by the framing approach. The notion of template schemata (e. g., Tesser, 1978; Hastie, 1981) defines a schema as a configuration of salient attributes; attributes are, in this context, regarded as slots with default values. Our basic model of cognitive schemata (see Figure 2; see also Scheufele, 2003: 92) distinguishes between (a) the object or relation of schema-reference and (b) the criteria applied to it. Similar to template schemata, I operationalize criteria as a configuration of attributes (Figure 2: Each shaded square is one attribute) that is typically applied to the object of a schema reference. The subject's 'victim-of-terrorism-schema' mentioned above, for instance, refers to 'victims of terrorism' and the subject, for example, applies criteria such as 'politician', 'hardliner in Middle East affairs', 'being killed', and so forth ${ }^{3}$.

The idea of cognitive schemata spanning a consistent frame entails psychological research. Network theories (e.g., Lindsey and Norman, 1977; Rumelhart and Norman, 1978), for example, conceive knowledge

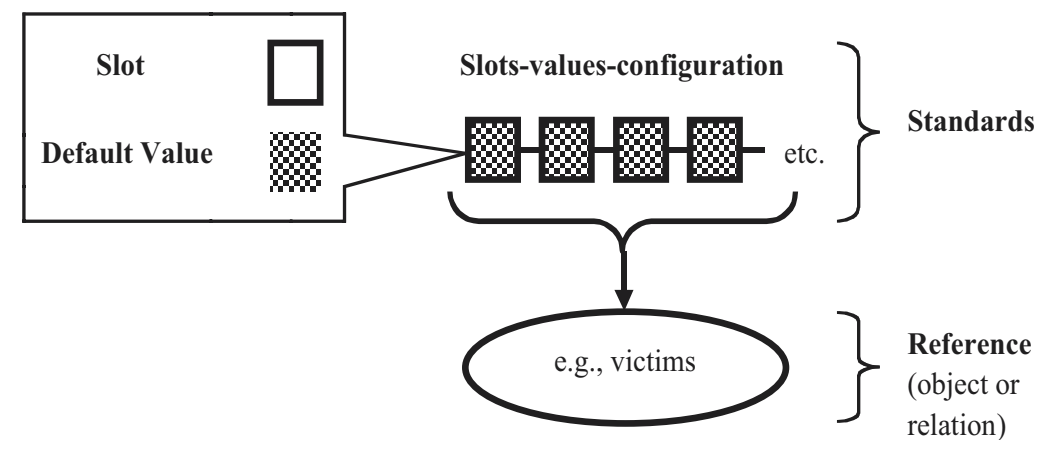

Figure 2. Basic model of cognitive schemata. 
as a network of knots. Recent theories (e. g., McClelland and Rumelhart, 1986) assume more complex structures with, between the knots, waves of activation. Hence, knowledge is regarded as a dynamic, adaptable pattern of activation (Clark, 1989: 92). From this point of view, a cognitive frame would be a configuration of schema-knots, repeatedly activated and, therefore, strongly connected. Similar ideas derive from phenomenology and public discourse studies. Neidhardt and Rucht (1993) assume that frame elements (problem definition, causes, consequences, values, etc.) form a consistent bundle. The notions of 'interpretative package' (Gamson and Modigliani, 1989: 3), 'closed field of meaning' (Schütz, 1971: 265), and 'border of expectations' (Goffman, 1993: 62) implicate the same.

This leads us to the following two presumptions with regard to the notion of framing. First, framing means stressing certain objects and relations. Hence, journalists or recipients may consider politicians to be typical victims of terrorism - and not normal citizens (objects). Or they may assume Middle East politics to be a typical cause for terrorism and not a clash of civilizations (causal relation). Secondly, framing also means applying certain standards to objects (e.g., to victims). Hence, journalists or recipients may perceive assassinations of politicians as typical acts of terrorism - in contrast to, for example, the bombing of Western cities. Here, different attributes are applied to the same object of 'terrorist attack' (see Figure 2).

Taking all this into consideration, a cognitive frame can be defined as a consistent bundle of schemata, which emerges in discourse, exchanges with other discourses and influences information processing. Take journalists for example; a journalistic frame (level of cognition) emerges in newsroom discourse (level of discourse), exchanges with other (media) discourses and influences news coverage (level of discourse product). Thus, the journalistic frame leads to a corresponding media frame.

\section{Theoretical critique on framing-effect studies and related approaches}

I will discuss the studies of framing-effects in three steps. First, I will apply a theoretical perspective extending recent considerations. Next, I shall classify empirical studies and discuss them in methodological terms. Finally, I will consider issues of measurement, questions and methodological chances that are left unanswered.

\section{Agenda-setting}

Similarities between framing, agenda-setting and priming have been pointed out by several researchers. Two positions can be distinguished: 
The first one favors agenda-setting as a global concept subsuming priming and framing (e. g., Ghanem, 1997; Takeshita, 1997); the second position regards agenda-setting as a variant of priming, which in turn needs to be separated from framing as a different mechanism of schema activation (e. g., Price and Tewksbury, 1997; Willnat, 1997). The first position is ill-founded, the second one is incomplete.

Following the agenda-setting hypothesis, media are expected not to influence how people think, but what they think (Cohen, 1963: 13). Recent studies on agenda-setting (e. g., McCombs and Ghanem, 2001) identify two levels. On a 'first level', agenda-setting is concerned with objects (i. e., issues and candidates). On a 'second level', agenda-setting influences cognitive and affective attributes. Thus, two different effects are mentioned:

Agenda-setting effect. In emphasizing an object (issue, candidate), the media determine whether recipients regard this object as important or not.

Attribute-setting effect. In emphasizing certain attributes of an object, the media influence the importance of these attributes for recipients.

From this point of view, the media do not only determine what we think, but also how we think (Ghanem, 1997: 4). Frames are considered attributes of objects, and framing itself as the selection of attributes (McCombs and Ghanem, 2001: 74). These considerations are not convincing for several reasons. First, although this division has been mostly neglected by McCombs and his colleagues, Benton and Frazier (1976) and Noelle-Neumann and Mathes (1987) had already distinguished between agenda-setting on the one hand and 'focusing' respectively 'evaluating' on the other hand. Therefore, the idea of two levels is nothing new at all. Second, the notion of issues is simply replaced by objects. Moreover, the construct of objects is restricted since most studies just ask for political candidates (e.g., Golan and Wanta, 2001). The notion of attributes is operationalized disparately, as 'perspective', 'frame', 'element' or 'compelling argument' (Ghanem, 1997; McCombs and Ghanem, 2001). Furthermore, the tendency of media coverage - respectively the attitudes of recipients - is now labeled as affective attributes which simply means introducing an artificial new term. Agenda-setting researchers (e.g., Gamson and Modigliani, 1989; Nelson et al., 1997; Scheufele, 2003), therefore, do not meet the demands for separating cognition from attitudes. Fourth, the idea of two levels of agenda-setting is barely convincing. Second-level studies merely study singular attributes, denying that schemata are specific configurations of attributes. More- 
over, the fact that a bundle of schemata forms a consistent frame of expectations is completely ignored (see also, Takeshita, 1997: 25). Furthermore, framing is not only a function of the attributes (standards) being applied to objects, but also a function of objects themselves. And finally, agenda-setting researchers leave psychological studies on attribute framing (Levin, Schneider, and Gaeth, 1998) out of consideration; these experiments proved that mentioning a positive or negative attribute of an object - which is called valence prime - determines whether a subject evaluates the object positively or negatively.

\section{Media priming}

By repeatedly covering a certain issue, the media not only establish an issue on the public agenda, but also provide issue-related criteria for evaluating, for instance, politicians (e. g., Iyengar and Kinder, 1987). Thus, agenda-setting can be seen as a springboard for media priming (Iyengar and Simon, 1993: 368; Pan and Kosicki, 1997: 11). Iyengar and Kinder (1987) follow the idea of 'availability heuristics'; subjects do not consider all relevant criteria for judgment, but merely those that are accessible at that moment. An issue covered by the media serves as a prime. Criteria that are activated by this 'issue-prime' remain accessible and can be activated again for judgment.

However, original psychological priming experiments show us that some differences exist. First, Ratcliff and McKoon (1978) made subjects memorize phrases with certain words - assuming that subjects build up word associations. In a recognition test subjects were asked to detect a target word in a sentence. The experimental group had been primed on a specific word from the memorized phrases before the target was presented. As expected, these primed subjects recognized the target word much more rapidly; the explanation that was given was that activation was spread between prime and target (Collins and Loftus, 1975). Second, Higgins et al. (1977) and Wyer and Srull (1981) presumed a cognitive link between trait and behavior. If subjects are primed on traits, they classify ambiguous behavior of a target person based on this trait-prime. Noteworthy is that behavior is operationalized as ambiguous, that the prime has to be applicable, and that people should not be conscious of the link; if people are aware of these factors, contrast effects can occur (Lombardi, Higgins, and Bargh, 1987). Third, classifying behavior by mentioning a trait is the most common dependent variable (see Higgins, Bargh, and Lombardi, 1985). However, other variables such as problem solving (Higgins and Chaires, 1980) should be examined as well. Fourth, priming effects tend to be intense when subjects have been primed recently (Higgins et al., 1985) or frequently (Srull and Wyer, 1979). There 
are different assumptions with regard to which of the two priming factors, that is, recent or frequent priming, dominates. According to the storage-bin model (Wyer and Srull, 1981) memory can be compared to a 'cognitive bucket'. Recently primed schemata can be recalled more easily, as they 'lie on top of the bucket'. The storage-battery model (Wyer and Carlston, 1979) presumes, that the 'battery' of schemata is charged repeatedly by frequent priming. According to the synapse model (Higgins et al., 1985), activation decreases more rapidly if a schemata has been primed more recently. For short periods between prime and target, recent priming dominates where longer decays support frequent priming. Most studies support the synapse model (Higgins, 1989; Higgins and Brendl, 1995). Regardless of the evidence available, a transfer of the psychological concept to mass communication appears to be problematic $^{4}$ :

(1) Media-priming totally ignores that media coverage is much more complex than a singular word or trait. Even a singular news report can prime differently or even in contradictory directions ${ }^{5}$. In short, media-priming studies adapt a hypothesis for micro stimuli for macro stimuli and, therefore, operate on the wrong level of analysis.

(2) Moreover, experiments on media-priming do not meet the actual conditions of media reception. Priming effects are dependent on cumulative and consonant news coverage of a certain issue. But longitudinal studies (Willnat and Zhu, 1996) or sequential experiments (Iyengar and Kinder, 1987) are rare.

\section{Schema activation through framing and priming}

In an attempt to separate agenda-setting, priming and framing, Price and Tewksbury (1997; see also Price et al., 1997) dock on three psychological constructs: Availability, accessibility and applicability (Higgins, 1989; Higgins and Brendl, 1995). An available schema exists in one's longterm memory. A schema is applicable when cues in new information supplement schema slots and, thus, activate the schema. An accessible schema that has been activated remains in the working memory and is more likely to be activated again. Furthermore, research distinguishes between chronic and temporal accessibility. Recent and frequent priming are said to be responsible for chronic accessibility.

Price and Tewksbury (1997) consider activation the crucial link between agenda-setting, priming and framing. In the case of framing, salient characteristics of media messages serve as cues that activate schemata whose slots comply (or fit) best with these media cues. What I call 'fitting' (Scheufele, 1999a) is seen as the core aspect of applicability. 
Applicability effects should occur during or shortly after the media reception (Price et al., 1997: 486). Furthermore, a schema, activated by framing, retains some residual activation. The schema is, therefore, more likely to be activated again for later judgment. This new activation is an accessibility effect which can be explained by priming. I expect that evaluation and decisions are, in the long run, influenced in two ways. On the one hand, the media prime recipients by reporting cumulatively on an issue; on the other hand, the media frame the issue consonantly ${ }^{6}$. Price and Tewksbury (1997) add the most convincing concept to separate agenda-setting, priming and framing; still, two deficits remain. First, they neither explain why recipients change existing schemata nor why they establish new ones. In other words, they merely study 'activation effects'. Secondly, they do not clarify why activating a schema should result in a certain judgment.

\section{Formation and transformation of cognition}

According to Scheufele (2003), theories on mental models (JohnsonLaird, 1980, 1989) or situational models (van Dijk, 1988) serve as an explanation for how the media can establish new schemata or change existing ones. Mental models are representations of a situation described in a newspaper article. For example, someone who reads an article on the conflict situation in the Middle East, has already formed some idea of this situation. Yet, s/he will change, broaden and redesign this model based on information in this article. Construction of such a model consists of three components: A representation of the article read so far, the schemata activated while reading the article, and the actual constructed model. Mental models have slots such as schemata that can be seen as the recipient's unanswered questions. These are either filled with information from the article or with the default values of the schema at hand. This enables recipients to update their knowledge (van Dijk and Kintsch, 1983: 342).

The frames in news coverage, that is the media-frames, and the already existing schemata of recipients converge in a specific way (Scheufele, 1999a). Three issues seem to be relevant (see Figure 3).

(1) Transforming schemata. Media are able to change recipients' already existing cognitions (circle in Figure 3) step-by-step (oval) by cumulative and consonant coverage until recipients have adapted their schema to the media-frame (rectangle).

(2) Changing cognitive links. Relational representations, for example, recipients' ideas of the causes of terrorism, can be conceived as a causal link between schema nodes in a cognitive network. If media repeatedly cover certain causal explanations, recipients' causal attributions 
Case 1: Attack-framing and transformation of the attack-schema (changes in standards, i.e., attribute configurations)

\section{Recipient: \\ Attack- \\ schema \\ Media: \\ Attack-}

framing
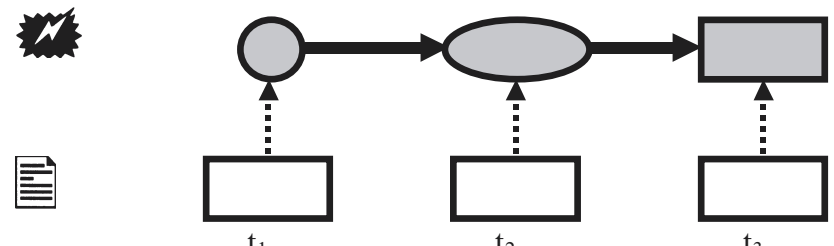

Case 2: Causal framing and transformation of causal cognitions

('redeployment' of the cognitive causal link)

Recipient:

Causal link

between schemata

Media:

Causal

framing
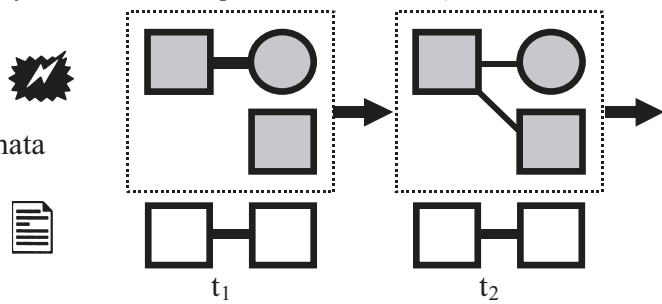

$t_{2}$

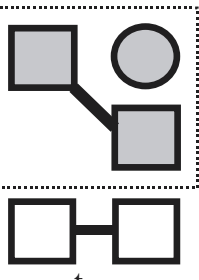

$t_{3}$

Case 3: Media-framing and establishing a specific sub-schema

Recipient:

Establishing

a specific sub-schema
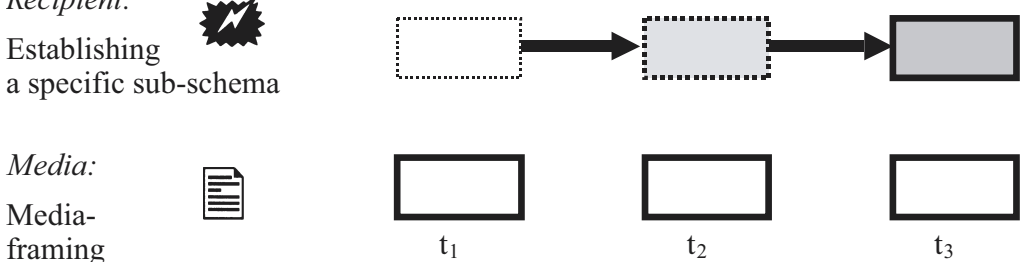

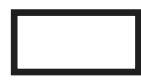

$\mathrm{t}_{1}$

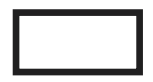

$t_{2}$

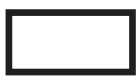

$t_{3}$

Transformation

associative (causal) link

$\square \bigcirc$ schemata

Figure 3. Transformation and formation effects.

(link to circle in Figure 3) tend to diminish for the benefit of a new causal link being suggested by media-framing (link to rectangle).

(3) Establishing new schemata. Recipients do not always dispose of a specific schema. In the case of xenophobic attacks, for instance, they rely on their general schema of violence at first. But according to the sub-typing model of schema theory (Fiske and Taylor, 1991) this schema for violence in general and an increasing media coverage on xenophobic attacks will interact, resulting in a new sub-schema for xenophobic attacks. 


\section{Attitudinal changes}

The framing approach focuses on realizing attitudinal changes. How activation or transformation of schemata results in attitudinal changes could be described using Fiske's (1982) 'schema triggered affect' or an inference from cognitive to affective aspects (Peeters, 1991). Here I rely on two more elaborate explanations. First, the theory of instrumental actualization (Kepplinger, Brosius, and Staab, 1991) does not refer to framing, but gives a similar explanation. According to Rosenberg (1956), people tend to have a positive attitude when an object is instrumental for core values (positive cognitions). On the contrary, negative cognitions result in a negative attitude. Kepplinger et al. (1991) argue that media alter recipients' cognitions by repeatedly covering certain attributes (e. g., waste disposal problems) of an object (e. g., nuclear energy). Next, recipients adapt their attitude to those cognitions made more salient by the media in order to reestablish a consistency between cognition and affect. Nelson et al. (1997) provide a similar explanation. Based on the persuasion approach (e.g., Hovland, Janis, and Kelley, 1953), one would expect recipients to change their attitudes based on new arguments introduced by the media. Conversely, the framing approach would lead one to assume that attitudes change because the media alter the salience of recipient's already existing cognitions. According to Fishbein and Ajzen (1975), people expect an object to have certain attributes (cognitive component), with expectations seen as weights, here. Moreover, each attribute is evaluated (affective component). The overall attitude towards the object results from the product sum of all attributes' weights and evaluations. From this, Nelson et al. (1997) provide an explication for framing effects, which can be illustrated by the following example; recipients expect nuclear energy to safeguard employment and give rise to waste disposal problems. As the two attributes of nuclear energy have the same weight, the overall attitude is ambivalent. However, if the media repeatedly report on disposal problems, they make this aspect of nuclear energy more salient, that is, disposal problems gain weight in the attitude product sum. As a consequence, the affect that is formed on disposal problems increases in importance as well and attitude tends to become more negative. However, from our point of view, this mechanism only takes place, if most recipients evaluate the attribute, which was made salient by media, in a similar manner.

As a final theoretical conclusion, I distinguish between four types of framing effects. Through media-framing, already existing schemata of recipients can be activated (activation effect) or modified (transformation effect). Schemata not yet existent can be established by media-framing (formation effect), and, finally, already existing attitudes can be altered (attitudinal effect). 
Table 1. Types of framing-effects.

\begin{tabular}{|c|c|c|}
\hline Label & Description & Mechanism \\
\hline $\begin{array}{l}\text { Activation } \\
\text { effect }\end{array}$ & $\begin{array}{l}\text { Activation of existing schemata } \\
\text { Repeated activation (Priming) }\end{array}$ & $\begin{array}{l}\text { Short-term applicability } \\
\text { Long-term accessibility }\end{array}$ \\
\hline $\begin{array}{l}\text { Transformation } \\
\text { effect }\end{array}$ & $\begin{array}{l}\text { Transforming existing schemata } \\
\text { in terms of the media-frame }\end{array}$ & $\begin{array}{l}\text { Consonant and cumulative } \\
\text { media coverage }\end{array}$ \\
\hline $\begin{array}{l}\text { Formation } \\
\text { effect }\end{array}$ & $\begin{array}{l}\text { Establishing totally new sche- } \\
\text { mata or links between schemata }\end{array}$ & Subtyping of schemata \\
\hline $\begin{array}{l}\text { Attitudinal } \\
\text { effect }\end{array}$ & $\begin{array}{l}\text { Switching existing } \\
\text { attitudes or opinions }\end{array}$ & $\begin{array}{l}\text { Shift in evaluative component } \\
\text { of attitudes through shift in } \\
\text { cognitive component }\end{array}$ \\
\hline
\end{tabular}

\section{A methodological and empirical critique on framing-effects studies}

A theoretical critique needs to be supplemented by a methodical as well as an empirical discussion of framing-effect studies. The exemplary studies selected here will be classified according to their independent variables in the first step, and according to their dependent variables, that is, the aforementioned types of framing effects, in the second step.

\section{Independent variables: Effects of different types of frames}

Referring to independent variables I distinguish between empirical studies examining effects of abstract or formal frames and studies referring to content-related frames ${ }^{7}$.

Formal frames. In the context of this article, media frames are labeled as formal or abstract when they do not refer to content. I conceive such stimuli as an equivalent to the schema-theoretical concept of formal schemata such as 'causality' (Kelley, 1972) or 'balance' (Axelrod, 1973).

Iyengar (1991) distinguishes between episodic and thematic framing. When framing episodically, the media focus on a singular case or exemplar, reminding us of prototypes (Rosch et al., 1976). When framing thematically, the media discuss an issue in more abstract terms. The dependent variable is the causal attribution. In the case of episodic framing, the singular person is made responsible for a problem or its solution, in case of thematic framing society is made responsible. Iyengar (1991) chose a multi method approach. In a number of field experiments, subjects watched TV news selected from a previous content analysis. The subjects either viewed an episodic or a thematic report, and were then asked questions concerning causal attribution. Additional survey data served to test further effects. I need not discuss results in detail here; there seems 
to be overall empirical evidence for the assumptions. However, one of the experiments concerning poverty indicated that it was not only the formal frame which influenced causal attribution, but also the attributes of persons presented in the news report. Moreover, framing effects were not found for unemployment, which could be considered a ceiling effect. The findings for discrimination and poverty among black people are problematic, since the frame stimulus seemed to have been influenced by other features in the news report.

Iyengar and Simon (1993) combined content analysis with survey data. Evening news during the 1990/91 Gulf crisis framed episodically and increasingly reported on a military engagement. Survey data proved that heavy viewers supported military action instead of diplomacy ${ }^{8}$. However, this can only be called a media-framing effect, if the majority of the episodic reports covered the military option; yet the contrary was true. Moreover, there was no longitudinal examination. In fact, media's increasing focus on military aspects as well as population's growing support for this option simply was due to the Gulf War in 1991. Thus, the correlation between media and recipients found in the study is quite artificial.

Rhee (1997) examined another type of formal framing by drawing on Patterson's (1993) argument of an increasing game schema in electoral coverage. Rhee (1997) speaks of a strategic frame, that is, media focus on candidates' strategies and debate rather than on issues. Conversely, a thematic frame report covers electoral issues. Recipients were presumed to follow the media frame, and to, subsequently, integrate it into their cognitions ${ }^{9}$. One experiment concerning a mayoral election manipulated the formal frame (strategy versus issue) and the media format (TV versus newspaper). A pre- and posttest recorded subjects' cognitions, that is, 'narrative representations of campaign interpretations' (Rhee, 1997: 35). Subjects who received a strategy report listed more strategic and less thematic aspects than subjects receiving an issue framed report, and vice versa. Moreover, subjects already thinking in certain categories were more susceptible to the corresponding media frame. Yet, findings were only significant for print coverage.

Rhee's (1997) study was part of a larger project carried out by Cappella and Jamieson $(1996,1997)$. The first part of the project concerned the mayoral election, the second one Clinton's health care plans. Knowledge, attitudes and political cynicism, among others, served as dependent variables. The sequential experiment concerning the mayoral election seemed to affirm the authors' assumption that strategy framing leads to political cynicism. Yet, the health care experiment did not lead to any evidence. The authors offer some explanations. The simplest explanation being that the stimulus had been superposed by subjects' reception of 
the actual debate on Clinton's health care plans. Thus, future experimental studies afford issues, which were not yet covered by any media. Furthermore, the thematic frame was operationalized with a problem bias, thus causing critical attitudes. Altogether, even the findings for the election issue were hardly significant and, therefore, did not support the cynicism thesis.

Shah et al. (1996, 2001) studied effects of value-framing, which marks the crossing from formal to contents-related frames. The authors distinguished between moral and materialistic framing and measured subjects' decisions for a political candidate. The decision was called compensatory, when subjects chose the candidate because of his position towards several issues; whereas the decision was labeled non-compensatory, when it was based on one criterion only. If subjects had read the morallybiased article, they applied corresponding standards more often than subjects reading the materialistic news report. Moreover, they were more likely to come to a non-compensatory decision.

Content-related frames. I call frames content-related if they refer to a meaning and not to some formal principle, in the way abstract frames do. For example, a formal frame would present a terrorist attack, for example, in episodic terms, whereas a content-related frame would refer to the Middle East problem or to religious conflicts, regardless of whether it is placed in an episodic mode or not.

Neuman, Just, and Crigler (1992) examined, for example, whether media and audience frames correspond. Comparisons of media and audience frames discovered similarities, but also differences, although neither could be considered not meaningful for several methodological reasons. An experiment conducted by Valkenburg et al. (1999) identified four experimental groups and one control group. Subjects had to read two articles on the Euro and on crimes. They were told to list all thoughts that came up while reading the articles (see Price et al., 1997); these thoughts were coded and factor-analyzed. Yet, it remains unclear what the relevant frames were. On the one hand, the authors manipulated four frames for the experiment; on the other hand, they identified frames from subjects' thoughts by factor analysis. Normally, one would merely check whether subjects reading an article with, for example, a 'conflict frame' listed more conflict-related thoughts than other subjects (such as, for example, Price et al., 1997). Nevertheless, multivariate analysis proved that frames influenced subjects' thoughts. Valkenburg et al. (1999), as well as Neuman et al. (1992) and Price et al. (1997) used frames, which had partially been identified in earlier content analyses; 
this meets 'original' media coverage. However, the 'news frames' - for example, 'conflict', 'consequences' or 'human interest' - are news factors. Price et al. (1997) acknowledged the theoretical link to news factor approach, arguing that, for example, a 'conflict frame' would structure a story specifically. Nevertheless, these 'news frames' remain news factors; Price et al. (1997: 484) themselves speak of 'news values'. In conclusion, the studies show that media users adopt news factors more easily than content-related frames. An example for such frames can be given from one of my own studies. I conducted an experiment using the issue 'Turkey's possible European Community membership' and two frames. The first frame discussed the possible membership in terms of human rights; the other in economic terms. These two frames are content-specific frames and are studied by the social movement approach (e.g., Snow and Benford, 1988), or more convincing framingeffects studies.

One of them is Iyengar's (1991) experiment concerning the Iran-Contra affair. The affair was framed differently in three experimental groups - for example, in terms of Reagan's credibility and knowledge of the affair. The subjects were asked for the reasons why weapons had been sold to Iran. The results identified differences among the groups which were partially significant. Findings from national surveys were similar, but indicated a clear partisan bias. Park and Kosicki (1995) also observed framing effects using the Iran-Contra affair. They distinguished two categories of frames: 'valence issues' (e.g., Reagan's incompetence) indicated that one could only hold a negative opinion, 'position issues' (e. g., arms for Lebanon hostages) indicated that subjects could have diverse opinions. The support for Reagan decreased for heavy TV viewers. To explain this, the authors drew upon content analysis data, which showed that negative valence frames dominated TV news. Yet, this conclusion is merely plausible, since data sets of content analysis and national surveys were not statistically combined.

Nelson et al. (1997) conducted an experiment on social welfare. In the first experimental group, the stimulus article frame welfare as a 'giveaway-program'. In the second group, social welfare was framed as an economic burden. The authors presumed that the poverty images activated by the first frame strongly correlated with attitudes towards welfare. Difference in correlated between experimental groups was seen as a framing effect. Correlation between images and attitudes were indeed stronger for the 'give-away-program' frame. Moreover, correlations were comparatively high among people with different issue knowledge. This supports the thesis that framing only alters weights of already existing cognitions. 


\section{Dependent variables: Types of framing-effects}

Studies will now be classified according to dependent variables, that is, the aforementioned types of framing effects. Here, some studies that do not use the framing label will be discussed as well.

Transfer of media frames and activation of recipients' schemata. The adoption of media-frames by recipients was examined by Neuman et al. (1992) as well as by agenda-setting researchers (e. g., Golan and Wanta, 2001). In the latter case, correlations between the frequency of attributes in coverage and in national surveys were calculated. In this case, I can raise similar objections, comparable to those that were raised for the Chapel-Hill study (McCombs and Shaw, 1972). The causal direction remains unclear and the high correlations can be ascribed to the problem of aggregate data. All studies suggest a linear correspondence of media and audience frames without discussing whether schema activation or schema transformation is involved. Furthermore, framing-effects are always an interaction of both, that is, media frames and recipients' already existing cognitions (Scheufele, 1999a; see also Johnson-Laird, 1980, 1989).

Activation effects were explicitly examined by Price et al. (1997). In one of two experiments with two experimental and one control group, subjects were asked to list thoughts after reading stimulus articles. Subjects followed the media frame. Subjects reading an article with a conflict frame, for instance, thought more often in terms of conflict than other subjects. The authors see this as a proof for an activation of subjects' cognitions. The aforementioned studies of Valkenburg et al. (1999) and Nelson et al. (1997) also seem to prove this type of framing-effect, yet they studied the adoption of news factors by media users rather than effects of content-related frames.

Formation and transformation of cognitions. Studies on framing have, so far, not provided any significant evidence for the type of framing-effects concerning the formation and transformation of cognitions. However, studies on information processing do give some indication for these effects. Früh (1991), for example, examined if the order in which information was presented in the lead of a news report suggested some kind of purport; this purport would, in turn, determine how subjects read the rest of the article. The experiment proved that subjects indeed followed the purport established by the information order. Furthermore, subjects did not process information at the end of the article; this in contrast to the 'frame' in the lead. Staab (1992) examined whether a TV news report concerning the economic situation in Eastern Germany - which was the first item of the evening news - had any impact on the recall of a news 
report on xenophobia which had been presented at the end of the evening news. Subjects who watched the economic report with a negative tenor were more likely to recall the xenophobia report. From our point of view, this finding can be explained as follows. Subjects linked the content of the reports and assumed that the economic deficits in Eastern Germany caused xenophobia. This could be considered indirect evidence for the formation of a causal cognitive link (see case 2 in Figure 3).

One report that is more convincing in terms of transformation effects, is Rhee's (1997) aforementioned experiment on strategy framing. Subjects' cognitions (thoughts) were measured both in a pre- and a posttest. Rhee also examined the intervention of media-framing effects by subjects' already existent schemata. Asking subjects to write letters about the mayoral election cognitions were measured quite comprehensive. Shah et al. $(1996,2001)$ considered subjects' value standards as an intervening factor in their experiment on value framing.

Attitudinal and emotional changes. The majority of the studies outlined so far focus on media-framing influencing attitudes, emotions or decisions of recipients. Most studies examine opinions on political candidates. Second level agenda-setting studies (e.g., Golan and Wanta, 2001; McCombs, Shaw, and Weaver, 1997) compare candidates' 'affective attributes' covered in the media and listed by respondents. The study of Park and Kosicki (1995) leads to more convincing results. They examined the impact of 'valence' and 'position issues' on respondents' opinions of Reagan. Media frames appeared to have some influence, but partisanship and images of the president were more influential.

Iyengar's (1991) experiments on episodic and thematic framing indicated spill-over effects from issue-related attribution on further judgment. The presidential performance, for instance, was rated more negatively if poverty was considered a societal problem. But the best predictor for opinions on Reagan was, again, partisanship. The experiment on the Iran-Contra affair also proved spill-over effects. Reagan's foreign politics, for instance, were appreciated less when the respondent considered Reagan responsible for the selling of arms to Iran. Iyengar's (1991) findings as well as those provided by Shah et al. $(1996,2001)$ suggest what I call a two-step-model. As sketched above, the media first activate certain recipients' cognitions, which alters attitudes or determines voting decisions. Nelson et al. (1997) examined framing-effects on issue-related opinions, whereas Iyengar and Simon (1993) explored respondents' support for military action respectively diplomacy in the Gulf War. And even political cynicism could be seen as an attitudinal effect of media- 
framing, if the findings of Cappella and Jamieson (1997) would have been significant. Finally, media-framing also seems to have an impact on recipients' emotions and affects, as proved by Price et al. (1997).

\section{Methodological and empirical conclusions}

From a synoptical perspective, the studies discussed so far allow for four major conclusions concerning methods and measurement:

(1) Field studies combining content analysis and survey data often rely on aggregate data (e.g., Golan and Wanta, 2001); therefore, they suffer from ecological fallacy. Furthermore, some studies (e. g., Park and Kosicki, 1995) do not converge data sets. Cross-lagged panels or time-series analysis, which allow for causal interpretations, are completely missing.

(2) Experiments often use real stimuli (e.g., Cappella and Jamieson, 1997; Price et al., 1997; Valkenburg et al., 1999); these stimuli meet media coverage much more than artificial stimuli. However, stimuli sometimes vary with regard to other attributes (e. g., Iyengar, 1991). Effects due to cumulative and consonant framing still require empirical examination; sometimes, however, the stimulus is presented sequentially least (e. g., Iyengar, 1991; Rhee, 1997).

(3) Recipients' cognitions are often explored by combinations of thoughtlisting and subsequent content or factor analyses (e. g., Price et al., 1997; Rhee, 1997; Shah et al., 1996; Valkenburg et al., 1999). Such procedures exceed the limited attribute-related questions of national surveys (e. g., Golan and Wanta, 2001).

(4) Exploring recipients' schemata in pretests (e.g., Rhee, 1997; Nelson et al., 1997) activates these schemata. Such priming makes them more accessible, which may cause an overlay of the framing-effect. A Solomon-plan could perhaps control for such 'double-measurement'. Nevertheless, this problem cannot be solved easily.

From an empirical perspective, the findings of the studies outlined here allow for two major conclusions:

(1) Intervening variables. While agenda-setting research has provided evidence for intervening variables (McCombs et al., 1997), more evidence is required with regard to framing-effects. Some recipient factors seem to be important; i.e., political attitudes, expertise and activity (Iyengar, 1991; Park and Kosicki, 1995; Nelson et al., 1997), issue-related opinions and schemata (e. g., Rhee, 1997; Nelson et al., 
1997), and value standards (Shah et al., 1996). Print coverage seems to have stronger effects (e.g., Cappella and Jamieson, 1997), but effects also seem to depend on the issue under study (e. g., Iyengar, 1991).

(2) Two-step-model. Many studies (e. g., Früh, 1991; Rhee, 1997; Valkenburg et al., 1999) support an interaction of media-frames and recipients' schemata. Moreover, several findings (e. g., Iyengar, 1991; Park and Kosicki, 1995; Nelson et al., 1997; Price et al., 1997; Shah et al., 1996) suggest what I called a two-step-model. In the first step, media-framing influences cognitions (schema activation, formation and transformation). In the second step, media-framing has an impact on recipients' judgments, attitudes, opinions, emotions and decisions.

\section{Shortcomings and suggestions}

A theoretical and a methodological critique has to be supplemented by some constructive methodological suggestions.

\section{Experiments and field studies}

Most experiments determine framing effects directly after the presentation of the stimulus. This, however, does not lead to any objective judgment or decision. It would be more valid to, for example, record dependent variables one week after the stimulus presentation. Furthermore, most experiments present the frame just once. Such designs may serve activation effects. All other types of framing effects (formation, transformation and attitudinal effects) are rather middle or long term and need sequential stimulus presentation, as suggested by, for example, Iyengar (1991). In conclusion, one-time presentation of the experimental frame stimulus is appropriate in most cases, since almost all studies focus on temporal activation effects.

Solutions for further problems can only be sketched here. First, one cannot simply theoretically define how abstract or specific a recipient's schema should be. If one wants to identify respondents' schemata from their answers to a thought-listing task, one has to define the level of abstraction empirically (see also footnote 2). Second, most experimental stimuli are news factors rather than frames (e. g., Price et al., 1997; Rhee, 1997; Valkenburg et al., 1999). Here, content analyses would be of great help to create stimuli meeting 'original' media-frames. Indeed, Price et al. (1997) and Valkenburg et al. (1999) realized this, although they focused on news factors rather than on content-specific frames. Third, experiments on formal frames hardly control for any diffusion between 
the frame and content - for example, with regard to the characteristics of the victims presented (Iyengar, 1991). For this purpose, a multi-factorial design would be meaningful. An experiment on an issue, such as terrorism, could manipulate, first, the formal frame (e. g., episodic versus thematic) and, second, the content-related frame (e.g., 'religious fanaticism' versus 'Middle East politics'). Finally, transformation effects (see Table 1) require repeated stimuli and measurement of the dependent variables.

With regard to field studies, panel designs meet cumulative and consonant coverage. Yet, two critical observations should be added. First, national surveys continuously explore opinions. Changes in respondents' opinions can be compared to changes in media-framing. Cross-lagged panels or time-series analyses would allow causal interpretations. However, media use should be captured in order to minimize the problem of aggregate data as discussed in the context of agenda-setting.

Second, field studies have some limitations in regard to the analysis of cognitions. The agenda-setting question is routinely asked in national surveys. Respondents' issue-related schemata cannot be identified through such a simple question. Thought-listing (Price et al., 1997) would be appropriate; this, however, is not applicable to continuous polling. An alternative would be to identify respondents' schemata whenever mediaframing shifts significantly. Unfortunately, shifts in coverage can only be observed afterwards. This would require an examination of respondents' schemata retrospectively which, however, is not possible.

A routine examination of recipients' schemata is difficult. Still, a standard instrument could be developed to analyze more 'routine issues' such as elections or wars. Developing such an instrument for elections requires a meta-analysis; this instrument could be based on previous studies that have used a thought-listing method of data collection. A synopsis of all thought-lists in election studies could result in a catalogue of schemata. This catalogue would, then, apply to elections, campaigns and candidates and could be translated into standard items for national surveys (Scheufele, 2003: 225).

\section{Tendency, frame-elements and media characteristics}

Future studies should examine if and to what extent the framing and evaluation of an issue interact. Presumably, there will be stronger effects for 'valence frames' (Park and Kosicki, 1995), that is, for frames with a corresponding tendency (see Scheufele, 2003: 82) ${ }^{10}$. Moreover, cumulative and consonant media-framing together with a distinct tendency can bring recipients to establish a link between cognition and attitude (formation effect: see Table 1). 
Most framing-effect studies operationalize media frames one-dimensionally; this implies an orientation towards 'prospect theory'. Surprisingly, valid arguments from the public discourse or social movement approach are completely ignored. These two approaches (e.g., Gamson, 1992; Gamson and Modigliani, 1989; Snow and Benford, 1988) define several frame-elements - for example, problem definition, causal reasoning, solutions or values. It is assumed, however, that a consistent relation between all frame-elements is necessary to create a powerful perspective. From my point of view, some frame-elements can be more effective than others, depending on the issue. For instance, in case of disasters, causal and responsibility considerations dominate. In these cases causal framing can be more powerful. In the case of scandals, political standards or social norms are violated. Hence, value framing may be more effective. Future research should also compare framing effects of controversial issues and framing effects of routine issues. In the latter case, recipients' cognitions should intervene media-framing - as suggested by findings on chronic accessibility in cognitive psychology (see Higgins, 1989). In conclusion, I call for an integration of the macroscopic sociological public discourse and social movement approach (e.g., Gamson, 1992; Gamson and Modigliani, 1989; Snow and Benford, 1988) and the microscopic psychological framing effects approach. The first approach on framing lacks convincing empirical evidence for media effects, while the framing effects approach fails to explain framing effects beyond the psychological micro-level and shows deficits with regard to the frame stimuli as well. Furthermore, the framing effects approach leaves open theoretical potential as well as methodological chances.

Finally, characteristics of news reporting should be considered in more detail. Psychological findings indicate, for instance, that recipients draw more inferences from thematically consistent texts (Schnotz, 1985). If this is applied to the concept of framing, the conclusion can only be that the degree of frame consistence could strengthen framing effects; maybe even a threshold value could be detected. Specific effects are probable for the visual format (Scheufele, 1999a, 2001); some studies have shown that recipients judge politicians on the visual image that is presented in the media (e. g., Baggaley, 1980; Spignesi and Shor, 1981). Moreover, a verbal and a visual frame can take an additively or divergently effect. Especially the main characteristic of television, that is, the sequential presentation of (moving) pictures suggests framing respectively priming effects. One should ask whether television frames are 'proactive' or even 'retrospective'. Effects of visual frames have rarely been examined, even though many studies (e.g., Entman 1991; Gamson Modigliani, 1989; 
Pan and Kosicki, 1993) emphasize the importance of visual framing. The few exceptions concern case studies (e.g., Gamson and Modigliani, 1989), focus on visual presentations in print media only (e. g., by counting the number of political cartoons; see Entman, 1991) or provide hermeneutic reasoning than quantitative findings (e.g., Kress and van Leeuwen, 1998).

This leads me to the following conclusions in regard to the theorizing on framing (statement 1), empirical evidence (statements 2 to 4 ) and methodological aspects (statements 5 to 7 ):

(1) I distinguished four types of framing effects, that is, activation, transformation, formation, and attitudinal effects. Most studies provide evidence for the first and fourth effect.

(2) Studies on attribute agenda-setting (e.g., Golan and Wanta, 2001) do not examine framing-effects but rather focus on valence priming effects (see Levin et al., 1998).

(3) Recent experiments (e. g., Price et al., 1997; Rhee, 1997; Valkenburg et al., 1999) examine effects of news factors on recipients' thoughts rather than effects of content-specific frames. So far, only studies on viewing (e.g., Iyengar, 1991; Nelson et al., 1997) provide empirical evidence for effects of content-related frames.

(4) Therefore, the framing effects approach should focus more on content-related frames, which are discussed in detail by public discourse and social movement (e.g., Gamson, 1992; Gamson and Modigliani, 1989; Snow and Benford, 1988).

(5) Framing approach still lacks a longitudinal design within the area of field studies, and repeated stimuli in experiments, with the exception of Iyengar (1991), while these are basic requirements for the study of formation and transformation effects. Furthermore, other media characteristics, such as the tendency of coverage, visual format, etc., also require further examination in terms of framing effects.

(6) Some experiments (e. g., Iyengar, 1991; Neuman et al., 1992; Price et al., 1997; Valkenburg et al., 1999) partly meet real reception situations by using original media material for experimental design. However, a larger number of field studies - such as the one presented by Park and Kosicki (1995) - should be conducted. The surveys conducted so far mostly rely on second level agenda-setting assumptions; in this article I have criticized various of these for several reasons.

(7) Recipients' cognitions are often explored by using a thought-listing method (e.g., Price et al., 1997; Rhee, 1997; Shah et al., 1996; Valkenburg et al., 1999); this method leads to much more profound ana- 
lyzes compared to questions asked in national surveys (e.g., Golan and Wanta, 2001). The instruments of thought-listing and openended questions should be adopted by future research.

\section{Notes}

1. With these levels we go beyond other classifications (e. g., Scheufele, 1999).

2. One might argue now that the schema theory also distinguishes between a general schema (e.g., for furniture) and sub-schemata (e.g., for chairs, desks). Thus, a frame would simply be sort of a major schema. I reject this objection for several reasons. First, sub-schemata are applied to a sub-set (e.g., chairs) of the same class of objects as the general schema (e.g., furniture). In contrast, the schemata setting up a frame refer to different classes of objects or relations. Second, schema hierarchies equate the issue and the frames applied to the issue. Two simple consideration prove that a distinction between issue and frame is necessary: The same frame can be applied to different issues. And different frames can be applied to one and the same issue (Scheufele, 2003). Finally, schema hierarchies also confuse the borders of internal schema structure and external links between schemata for different object classes. All these problems require a pragmatic solution such as the one provided here. I do not deny that my terminological solution also raises some problems. If one wants to extract recipients' schemata from their answers in questionnaires, one cannot simply fix the schema level theoretically. Instead, one should take the most frequent level of all answers from one recipient as a criterion for his or her schema level (also see Scheufele, 2001b, 2003).

3. One might argue against the schema theory that, first, the schema theory is criticized for its static view on cognition. Indeed, theories of parallel distributed processing (McClelland and Rumelhart, 1986) meet cognitive dynamics much better. Yet, they mostly cannot be operationalized for complex aspects of communication approach such as media content and more elaborate information processing. Furthermore, it has been argued that the existence of schemata could not be falsified at all. In other words, one can hardly find any results which can not be explained by schema theory (Alba and Hasher, 1983; Fiske and Taylor, 1991). Yet, this objection can be raised for other constructs such as 'attitude' or 'role' as well. In terms of measurement schema, concepts continue to be more practicable than, for example, theories of parallel distributed processing.

4. Even recent literature overviews (Peter, 2002) do not see this crucial point. Besides, Peter (2002) does not go far beyond the seminal work of Higgins and colleagues (e. g., Higgins and Brendl, 1995).

5. Furthermore, coverage probably not only primes on a issue, but also on certain tendencies, respectively evaluations (Pan and Kosicki, 1997: $10 \mathrm{ff}$.).

6. Noelle-Neumann (1973; Noelle-Neumann and Mathes, 1987) as well as the cultivation approach (e. g., Gerbner Morgan and Signorielli, 1999; Signorielli and Morgan, 1990) comprehend cumulative and consonant news reporting as a crucial condition for powerful media effects as well.

7. De Vreese, Peter, and Semetko (2001) distinguish between 'generic' and 'issuespecific' frames.

8. Iyengar and Simon (1993: 379) rely on experimental findings concerning delinquency (Iyengar, 1991). Subjects watching episodic reports supported punishment, while subjects watching thematic reports asked for an engagement of society.

9. Here, Rhee (1997) relies on the concept of mental models mentioned above.

10. A similar argument was provided by De Vreese and Boomgarden (2003). 


\section{References}

Alba, J. and Hasher. L. (1983). Is memory schematic? Psychological Bulletin, 93, $203-231$.

Axelrod, R. (1973). Schema theory: An information processing model of perception and cognition. American Political Review, 67, 1248-1266.

Baggaley, J. (1980): Psychology of the TV image. Farnborough: Gower.

Benton, M. and Frazier, P. J. (1976). The agenda-setting of the mass media at three levels of 'information-holding'. Communication Research, 3, 261-274.

Cappella, J. N. and Jamieson, K. H. (1996). News frames, political cynicism, and media cynicism. In K. H. Jamieson (Ed.), The annals of the American Academy of Political and Social Science (546) (pp. 71-84). Thousand Oaks, CA: Sage.

Cappella, J. N. and Jamieson, K. H. (1997). Spiral of cynicism. The press and the public good. New York: Oxford University Press.

Clark, A. (1989). Microcognition: Philosophy. Cognitive science, and parallel distributed processing. Cambridge, MA: Harvard University Press.

Cohen, B. C. (1963). The Press and foreign policy. Princeton, NJ: Princeton University Press.

Collins, A. M. and Loftus, E. F. (1975). A spreading-activation theory of semantic processing. Psychological Review, 82, 407-428.

De Vreese, C. H., Peter, J., and Semetko, H. A. (2001). Framing politics at the launch of the euro: A cross-national comparative study of frames in the news. Political Communication, 18, 107-122.

De Vreese, C. H. and Boomgarden, H. (2003). Valenced news frames and public support for the EU: Linking content analysis and experimental data. The European Journal of Communication, 3, 261-281.

Dijk, T. A. van (1988). News as discourse. Hillsdale, NJ: Erlbaum.

Dijk, T. A. van and Kintsch, W. (1983). Strategies of discourse comprehension. New York: Academic Press.

Entman, R. M. (1991). Framing U.S. coverage of international news: Contrasts in narratives of the KAL and Iran air incidents. Journal of Communication, 41, 6-27.

Entman, R. M. (1993). Framing: Towards clarification of a fractured paradigm. Journal of Communication, 43, 51-58.

Entman, R. M. and Rojecki, A. (1993). Freezing out the public: Elite and media framing of the U.S. anti-nuclear movement. Political Communication, 10, 155173.

Fishbein, M. and Ajzen, L. (1975). Belief, attitude, intention and behavior. An introduction to theory and research. Reading, MA: Addisson Wesley.

Fiske, S. T. (1982). Schema-triggered affect: Applications to social perception. In M. S. Clark and S. T. Fiske (Eds.), Affect and cognition: The 17th Annual Carnegie Symposium on Cognition (pp. 55-78). Hillsdale, NJ: Erlbaum.

Fiske, S. T. and Taylor, S. E. (1991). Social cognition (2nd ed.). New York: MacGraw-Hill.

Früh, W. (1991). Der aktive Rezipient - neu besehen. Zur Konstruktion faktischer Information bei der Zeitungslektüre. In W. Früh (Ed.), Medienwirkungen: Das dynamisch-transaktionale Modell. Theorie und empirische Forschung (pp. 237258). Opladen: Westdeutscher Verlag.

Gamson, W. A. (1992). Talking politics. New York: Cambridge University Press.

Gamson, W. A. and Modigliani, A. (1989). Media discourse and public opinion on nuclear power: A constructionist approach. American Journal of Sociology, 95, $1-37$. 
Gerbner, G., Morgan, M., and Signorielli, N. (1999). Profiling television violence. In K. Nordenstreng (Ed.), International media monitoring (pp. 335-365). Cresskill, NJ: Hampton Press.

Ghanem, S. (1997). Filling the tapestry: The second level of agenda-setting. In M. McCombs, D. L. Shaw, and D. Weaver (Eds.), Communication and democracy. Exploring the intellectual frontiers in agenda-setting-theory (pp. 3-14). Mahwah, NJ: Erlbaum.

Gitlin, T. (1980). The whole world is watching: Mass media in the making and unmaking of the new left. Berkeley, CA: University of California Press.

Goffman, E. (1993). Rahmen-Analyse. Ein Versuch über die Organisation von Alltagserfahrungen (3rd ed.). Frankfurt am Main: Suhrkamp Taschenbuch.

Golan, G. and Wanta, W. (2001). Second-level agenda-setting in the New Hampshire primary: A comparison of coverage in three newspapers and public perceptions of candidates. Journalism and Mass Communication Quarterly, 78, 247-259.

Higgins, E. T. (1989). Knowledge accessibility and activation: Subjectivity and suffering from unconscious sources. In J. S. Uleman and J. A. Bargh (Eds.), Unintended thought: The limits of awareness, intention and control (pp. 75-123). New York: Guilford Press.

Higgins, E. T., Herman, C. P., and Zanna, M. P. (1981). Social cognition. The Ontario Symposium (Vol. 1). Hillsdale, NJ: Erlbaum.

Higgins, E. T., Bargh, J. A., and Lombardi, W. J. (1985). Nature of priming effects on categorization. Journal of Experimental Psychology: Learning, Memory, and Cognition, 11, 59-69.

Higgins, E. T. and Brendl, C. M. (1995). Accessibility and applicablity: Some 'activation rules' influencing judgment. Journal of Experimental Psychology, 31, 218243.

Higgins, E. T. and Chaires, W. M. (1980). Accessibility of interrelational constructs: Implications for stimulus encoding and creativity. Journal of Personality and Social Psychology, 16, 348-361.

Higgins, E. T., Rholes, W. S., and Jones, C. R. (1977). Category accessibility and impression formation. Journal of Personality and Social Psychology, 13, 141-154.

Hovland, C. I., Janis, I. L., and Kelley, H. H. (1953). Communication and persuasion. New Haven, CT: Yale University Press.

Iyengar, S. (1991). Is anyone responsible? How television frames political issues. Chicago, IL: University of Chicago Press.

Iyengar, S. and Kinder, D. R. (1987). News that matters: Television and American opinion. Chicago, IL: University of Chicago Press.

Iyengar, S. and Simon, A. (1993). News coverage of the Gulf crisis and public opinion. A study of agenda setting, priming and framing. Communication Research, 20, $365-383$.

Johnson-Laird, P. N. (1980). Mental models in cognitive science. Cognitive Science, 4, $71-115$.

Johnson-Laird, P. N. (1989). Mental models. In M. I. Posner (Ed.), Foundations of cognitive science (pp. 469-499). Cambridge, MA: MIT Press.

Kelley, H. H. (1972). Causal schemata and the attribution process. In E. E. Jones, D. E. Kanouse, H. H. Kelley, R. E. Nisbett, S. Valins, and B. Weiner (Eds.), Attribution: Perceiving the causes of behavior (pp. 151-174). Morristown, NJ: General Learning Press.

Kepplinger, H. M., Brosius, H.-B., and Staab, J. F. (1991). Opinion formation in mediated conflicts and crisis: A theory of cognitive-affective media effects. International Journal of Public Opinion Research, 3, 132-156. 
Kinder, D. R. and Sanders, L. M. (1990). Mimicking political debate with survey questions: The case of white opinion on affirmative action for blacks. Social Cognition, 8, $73-103$.

Kress, G. and van Leeuwen, T. (1998). Front pages: (The critical) analysis of newspaper layout. In A. Bell and P. Garrett (Eds.), Approaches to media discourse (pp. 186-219). Oxford: Blackwell.

Levin, I. P., Schneider, S. L., and Gaeth, G. J. (1998). All frames are not created equal: A typology of and critical analysis of framing effects. Organizational Behavior and Human Decision Processes, 76, 149-188.

Lindsey, P. M., and Norman, D. A. (1977). Human information processing. An introduction to psychology. London: Academic Press.

Lombardi, W. J., Higgins, E. T., and Bargh, J. A. (1987). The role of consciousness in priming effects on categorization. Assimilation versus contrast as a function of awareness of the priming task. Personality and Social Psychology Bulletin, 13, 411-429.

McClelland, J. L. and Rumelhart, D. E. (1986). Parallel distributed processing. Vol. 2 : Psychological and biological models. Cambridge, MA: Harvard University Press.

McCombs, M. and Ghanem, S. I. (2001). The convergence of agenda setting and framing. In S. D. Reese, O. H. Gandy, and A. E. Grant (Eds.), Framing public life. Perspectives on media and our understanding of the social world (pp. 67-81). Mahwah, NJ: Erlbaum.

McCombs, M. E. and Shaw, D. L. (1972). The agenda-setting function of mass media. Public Opinion Quarterly, 36, 176-187.

McCombs, M., Shaw, D. L., and Weaver, D. (1997). Communication and democracy. Exploring the intellectual frontiers in agenda-setting-theory. Mahwah, $\mathrm{NJ}$ : Erlbaum.

Neidhardt, F. and Rucht, D. (1993). Auf dem Weg in die 'Bewegungsgesellschaft'? Soziale Welt, 44, 305-326.

Nelson, T. E., Oxley, Z. M., and Clawson, R. A. (1997). Toward a psychology of framing effects. Political Behavior, 19, 221-246.

Neuman, W. R. , Just, M. R., and Crigler, A. N. (1992). Common knowledge. News and the construction of political meaning. Chicago, IL: University of Chicago Press.

Noelle-Neumann, E. (1973). Kumulation, Konsonanz und Öffentlichkeitseffekt. Ein neuer Ansatz zur Analyse der Wirkung der Massenmedien. Publizistik, 18, 26-55.

Noelle-Neumann, E. and Mathes, R. (1987). The 'event as event' and the 'event as news': The significance of 'consonance' for media effects research. European Journal of Communication, 2, 391-414.

Pan, Z. and Kosicki, G. M. (1993). Framing analysis: An approach to news discourse. Political Communication, 10, 55-75.

Pan, Z. and Kosicki, G. M (1997). Priming and media impact on the evaluations of the president's performance. Communication Research, 24, 3-30.

Park, E. and Kosicki, G. M. (1995). Presidential support during the Iran-contra-affair: People's reasoning process and media influence. Communication Research, 22, $207-236$.

Patterson, T. (1993). Out of Order. New York: Knopf.

Peter, J. (2002). Medien-Priming - Grundlagen, Befunde und Forschungstendenzen. Publizistik, 47, 21-44.

Peeters, G. (1991). Evaluative inference in social cognition: The role of direct versus indirect evaluation and positive-negative asymmetry. European Journal of Social Psychology, 21, 131-146.

Price, V. and Tewksbury, D. (1997). News values and public opinion: A theoretical account of media priming and framing. In G. Barnett and F. J. Boster (Eds.), Progress in the communication sciences (pp. 173-212). Greenwich, CT: Ablex. 
Price, V., Tewksbury, D., and Powers, E. (1997). Switching trains of thought: The impact of news frames on reader's cognitive responses. Communication Research, $24,481-506$.

Ratcliff, R. A. and McKoon, G. (1978). Priming an item recognition. Evidence for the propositional structure in sentences. Journal of Verbal Learning and Verbal Behavior, 17, 403-417.

Reese, S. D. (2001). Prologue - Framing public life: A bridging model for media research. In S. D. Reese, O. H. Gandy, and A. E. Grant (Eds.), Framing public life. Perspectives on media and our understanding of the social world (pp. 7-31). Mahwah, NJ: Erlbaum.

Rhee, J. W. (1997): Strategy and issue frames in election campaign coverage: A social cognitive account of framing effects. Journal of Communication, 47, 26-48.

Rogers E. M. and Dearing, J. W. (1988). Agenda-setting research: Where has it been, where is it going? In J. H. Anderson (Ed.), Communication Yearbook (Vol. 11) (pp. 555-594). Newbury Park, CA: Sage.

Rosch E. H., Mervis, C. B., Johnson, D. and Boyes-Braem, P. (1976). Basic objects in natural categories. Cognitive Psychology, 8, 573-605.

Rosenberg, M. J. (1956). Cognitive structure and attitudinal affect. Journal of Abnormal Social Psychology, 53, 367-372.

Rumelhart, D. E. and Norman, D. A. (1978). Accretion, tuning, and restructuring: Three models of learning. In J. W. Cotton and R. L. Klatzky (Eds.), Semantic factors in cognition (pp. 37-53). Hillsdale, NJ: Erlbaum.

Scheufele, B. (1999a). (Visual) Media Framing und Politik. Zur Brauchbarkeit des Framing-Ansatzes im Kontext (visuell) vermittelter politischer Kommunikation und Meinungsbildung. In W. Hofmann (Ed.), Die Sichtbarkeit der Macht. Theoretische und empirische Untersuchungen zur visuellen Politik (pp. 91-107). BadenBaden: Nomos.

Scheufele, B. (1999b). Mediendiskurs, Medienpräsenz und das World Wide Web. Wie 'traditionelle' Medien die Einschätzung der Glaubwürdigkeit und andere Vorstellungen von World Wide Web und Online-Kommunikation prägen können. In P. Rössler and W. Wirth (Eds.), Glaubwürdigkeit im Internet. Fragestellungen, Modelle, empirische Methoden (pp. 69-88). München: Reinhard Fischer.

Scheufele, B. (2000). 'Scattered' or related - clarifying the framing concept by integrating related approaches? In H.-B. Brosius (Ed.), Kommunikation über Grenzen und Kulturen (Schriftenreihe der Deutschen Gesellschaft für Publizistik- und Kommunikationswissenschaft; Bd. 27) (pp. 381-396). Konstanz: UVK.

Scheufele (2003). Frames - Framing - Framing-Effekte. Theoretische und methodische Grundlegung sowie empirische Befunde zur Nachrichtenproduktion. Wiesbaden: Westdeutscher Verlag.

Scheufele, B. and Brosius, H.-B. (1999). The frame remains the same? Stabilität und Kontinuität journalistischer Selektionskriterien am Beispiel der Berichterstattung über Anschläge auf Ausländer und Asylbewerber. Rundfunk und Fernsehen, 47, 409-432.

Scheufele, D. (1999). Framing as a theory of media effects. Journal of Communication, 49, $103-122$.

Schnotz, W. (1985). Selectivity in drawing inferences. In G. Rickheit and H. Strohner (Eds.), Inferences in text processing (pp. 287-326). Amsterdam: North-Holland.

Schütz, A. (1971). Gesammelte Aufsätze (Band 1: Das Problem der Wirklichkeit). Den Haag: Nijhoff.

Shah, D. V., Domke, D., and Wackman, D. B. (1996). 'To thine own self be true'. Values, framing, and voter decision-making strategies. Communication Research, $23,509-560$. 
Shah, D. V., Domke, D., and Wackman, D. B. (2001). The effects of value-framing on political judgment and reasoning. In S. D. Reese, O. H. Gandy, and A. E. Grant (Eds.), Framing public life. Perspectives on media and our understanding of the social world (pp. 227-243). Mahwah, NJ: Erlbaum.

Signorielli, N. and Morgan, M. (1990). Cultivation analysis: New directions in media effects research. Newbury Park, CA: Sage.

Snow, D. A. and Benford, R. D. (1988). Ideology, frame resonance, and participant mobilization. International Social Movement Research, 1, 197-217.

Spignesi, A. and Shor R. E. (1981). The judgment of emotion from facial expressions, contexts, and their combination. The Journal of General Psychology, 104, 41-58.

Srull, T. K. and Wyer, R. S. (1979). The role of category accessibility in the interpretation of information about persons: Some determinants and implications. Journal of Personality and Social Psychology, 37, 1660-1672.

Tankard, J. W. (2001). The empirical approach to the study of media framing. In S. D. Reese, O. H. Gandy, and A. E. Grant (Eds.), Framing public life. Perspectives on media and our understanding of the social world (pp. 95-106). Mahwah, NJ: Erlbaum.

Tesser, A. (1978). Self-generated attitude change. In L. Berkowitz (Ed.), Advances in experimental social psychology (Vol 11, pp. 233-289). New York: Akademic Press.

Tuchman, G. (1972). Making news by doing work: Routinizing the unexpected. American Journal of Sociology, 79, 110-131.

Tuchman, G. (1978). Making news. A study in the construction of reality. New York: Knopf.

Valkenburg, P. M., Semetko, H. A., and Vreese, C. H (1999). The effects of news frames on readers' thoughts and recall. Communication Research, 26, 550-569.

Wicks, R. H. (1992). Schema theory and measurement in mass communication research: Theoretical and methodological issues in news information processing. In S. A. Deetz (Ed.), Communication Yearbook (Vol. 15; pp. 115-145). Newbury Park, CA: Sage.

Willnat, L. and Zhu, J.-H. (1996). Newspaper coverage and public opinion in Hong Kong: A time-series analysis of media priming. Political Communication, 13, $221-246$.

Willnat, L. (1997). Agenda setting and priming: Conceptual links and differences. In M. McCombs, D. L. Shaw, and D. Weaver (Eds.), Communication and democracy. Exploring the intellectual frontiers in agenda-setting-theory (pp. 51-66). Mahwah, NJ: Erlbaum.

Woo, J. (1996). Television news discourse in political transition: Framing the 1987 and 1992 Korean presidential elections. Political Communication, 13, 63-80.

Wyer, R. S. and Carlston, D. E. (1979). Social cognition, inference, and attribution. Hillsdale, NJ: Erlbaum.

Wyer, R. S. and Srull, T. K. (1981). Category accessibility: Some theoretical and empirical issues concerning the processing of social stimulus information. In E. T. Higgins, C. P. Herman, and M. P. Zanna (Eds.), Social cognition. The Ontario Symposium (Vol. 1; pp. 161-197). Hillsdale, NJ: Erlbaum. 